\title{
Microbial Population Succession in Alcoholic Beverages Produced from Some Tropical Fruits
}

\author{
Sanjay Mishra ${ }^{1,2, *}$, Surabhi Nanda ${ }^{2}$, Nidhi Madaan ${ }^{2}$ and Varsha Mudgal ${ }^{2}$ \\ ${ }^{I}$ Department of Biotechnology, College of Engineering \& Technology, IFTM Campus, Delhi Road, Moradabad 244 001, \\ U.P., India \\ ${ }^{2}$ Department of Biotechnology \& Microbiology, Institute of Foreign Trade \& Management, Lodhipur-Rajput, Delhi \\ Road, Moradabad 244 001, U.P., India
}

\begin{abstract}
In the present study, monoculture and mixed culture fermentation techniques were employed to produce certain alcoholic beverages from watermelon; watermelon-banana and watermelon-pineapple mixtures. Three yeast species, namely, Saccharomyces cerevisiae, Kleochera apicalata, Torulospora delbruckii and four bacterial species Leuconostoc oenos, Lactobacillus Sp, Micrococcus luteus and Streptococcus lactis were identified. The daily succession of these organisms in the various fermenting samples differed in cell mass and occurrence due to their different growth conditions and factors present. A higher bacterial load $(3.9 \pm 0.2-4.4 \pm 0.3) \log (\mathrm{cfu}) \mathrm{ml}^{-1}$ than yeast $(2.8 \pm 00-4.6 \pm 0.4)$ $\log (\mathrm{cfu}) \mathrm{ml}^{-1}$ counts was observed in the mixed culture fermentation, while in the monoculture fermentation, a higher

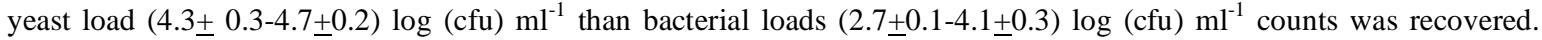
These results reflected that monoculture-fermented beverages were of better quality as compared to the mixed culture fermented ones, and the monoculture-fermented beverage from watermelon-pineapple mixture was ranked as the best alcoholic beverage.
\end{abstract}

Keywords: Beverages, fermentation, microbiological quality, tropical fruits.

\section{INTRODUCTION}

Principally, distinctive flavours of wine originate from different types of raw materials during alcoholic and malolactic fermentation [1,2]. All over the world, different raw materials are used for the production of alcoholic beverages traditionally. The forms of alcoholic beverage consumed in various regions of the world vary considerably in accordance to location and ingredients [3].

There has been some controversy over the relative merits of spontaneous fermentations with natural flora of the 'must' and fermentation carried out with selected yeast strains. While it was found that spontaneous fermentation produced a better rounded and more complex aromatic quality [4], a subsequent study concluded it a significant preference for wine produced with selected yeast $[5,6]$.

Seeding of the fermentation is undertaken with the assumption and expectation that the inoculated strain will outcompete and dominate over indigenous strains of Saccharomyces cerevisiae and the non-saccharomyces yeasts. Although there is high probability that inoculated $S$. cerevisiae will dominate the fermentation, seeding will not necessarily guarantee the dominance of any particular strain or its exclusive contribution in the fermentation [7-10].

\footnotetext{
*Address correspondence to this author at the Department of Biotechnology \& Dean (Research), College of Engineering \& Technology, IFTM Campus, Lodhipur-Rajput, Delhi Road, Moradabad 244 001, U.P., India;

Tel: +91-9837096059; E-mail: sanjaymishra66@gmail.com
}

The present studies were undertaken in view of gathering information on microbial population succession in alcoholic beverage produced from some tropical fruits through mixed and monoculture fermentation, and the impact of fermentation strategy and fruit mixture on the beverage quality.

\section{MATERIALS AND METHODS}

Tropical fruits, mainly, watermelon (Citrullus lunatus Thumb) banana (Musa sapientum) and pineapple (Ananas comosus) were procured from local farms in the close vicinity to Moradabad, U.P., India. All containers and appliances used in the study were properly sterilized and the fruits were processed under aseptic conditions.

The first treatment set up involved a homogenate of $8000 \times \mathrm{g}$ of watermelon. The $2^{\text {nd }}$ treatment contained $8000 \times \mathrm{g}$ each of homogenized watermelon and banana while the $3^{\text {rd }}$ treatment was a homogenate of $8000 \times \mathrm{g}$ each of watermelon and pineapple. However, each of the treatments was replicated for (monoculture and mixed culture) fermentations, simultaneously. The process fermentation was carried out at room temperature of $28 \pm 2^{0} \mathrm{C}$. In the mixed culture fermentation, indigenous microflora of the fruits were allowed for the fermentation while in the monoculture, the substrates were seeded with Saccharomyces cerevisiae of quantity $8.62 \mathrm{log}$ cfu ml- ${ }^{1}$ to overgrow the indigenous microflora of the fruits. All the treatments were allowed to ferment for one week.

At every $24 \mathrm{~h}$, the samples were aseptically withdrawn from the fermentors, serially diluted and $1 \mathrm{ml}$ each pure laced 
in triplicates on nutrient agar (NA) and incubated at $30^{\circ} \mathrm{C}$ for $24 \mathrm{~h}$ (bacterial growth) and potato dextrose agar (PDA) incubated at $28^{\circ} \mathrm{C}$ for $72 \mathrm{~h}$ (molds and yeast growth), in accordance to a standardized protocol [11]. Resultant colonies were enumerated with the aid of Gallenkamp colony counter, purified by streaking technique on freshly prepared NA and PDA; characterized and identified by a standard protocol [12]. Yeasts were identified by using Kreger [13] protocol.

The filtered beverage samples were tested for sensory evaluation using the multiple comparison tests [14]. The sensory parameters evaluated were taste, colour, aroma and overall acceptability. The filtered beverage samples were served chilled in white glass cups in an open space under bright daylight. With a 10-member panel of regular local beverage consumers, three glass cups each from each replicate were served. The parameters were rated on a 9-point hedonic scale. The Dunnett test was applied to determine significant results. The ratings were described as dislike extremely (1), dislike very much (2), no preference (5), like slightly (6), like moderately (7), like very much (8) and like extremely (9).

The data obtained were analyzed using the analysis of variance (ANOVA) to determine differences $[15,16]$ and Duncan's Multiple Range Test (DMRT) to separate the means [17].

\section{RESULTS}

Present study includes the identification of seven different microorganisms. Four were bacterial species including Micrococcus luteus, Leuconostoc oenos, Lactobacillus sp and Streptococcus lactis while three were yeast species, namely, Kleockera apiculata, Torulospora delbruckii and
Saccharomyces cerevisiae. Among these organisms, only Saccharomyces cerevisiae persisted throughout the period of fermentation in both the monoculture and mixed cultures. Leuconostoc oenos and Lactobacillus sp were not identified in the fermenting musts at the early stages of fermentation but were prominent toward the end of the fermentation duration. On the other hand, K. apiculata and T. delbruckii were present in the first two days of fermentation and could not be isolated from the must thereafter.

S. cerevisiae counts in the fermenting musts showed an increasing trend during the course of fermentation. Though substantial yeast counts were recorded in the mixed culture fermentation, it was found higher in the monoculture fermentation.

Generally, the mixed culture fermented samples had more bacterial population (Table 1) as compared to yeast (Table 2). In the watermelon fermenting medium, bacterial counts of $4.3 \pm 0.1-4.4 \pm 0.3 \log (\mathrm{cfu}) \mathrm{ml}^{-}{ }^{1}$ were observed, in watermelon-banana mixture medium, a lower yeast $(3.6 \pm$ $\left.0.1-4.1 \pm 0.2 \log (\mathrm{cfu}) \mathrm{ml}^{-1}\right)$ and higher bacterial $(4.3 \pm 0 . \overline{3}$ $\left.-4.4 \pm 0.3 \log (\mathrm{cfu}) \mathrm{ml}^{1}{ }^{1}\right)$ counts were, however, recorded. The microbial count in watermelon-pineapple mixture was the lowest, having bacterial counts of $3.9 \pm 0.3-4.4 \pm 0.1$ $\log (\mathrm{cfu}) \mathrm{ml}^{-}{ }^{1}$ and yeast counts of $2.8-4.1 \pm 0.1 \log (\mathrm{cfu})$ ml- ${ }^{1}$.

The bacterial counts observed in the monoculture, generally were lower than the counts in mixed culture fermentation. Bacterial counts in watermelon were $3.0-4.1 \pm 0.3 \log$ (cfu) $\mathrm{ml}^{-1}$, while yeast counts was $4.0 \pm 0.2-4.7 \pm 0.2 \mathrm{log}$ (cfu) $\mathrm{ml}^{-1}$

Table 1. Total Bacterial Counts (log (cfu) $\mathrm{ml}^{-1} \pm$ S.D) During the Course of Mixed Culture Fermentation. Values are Means \pm S.D of Three Sets of Experiments with Triplicate in Each Set

\begin{tabular}{|c|c|c|c|}
\hline Day & Watermelon & Watermelon+Banana & Watermelon+Pineapple \\
\hline \hline 0 & $4.3 \pm 0.1$ & $4.3 \pm 0.3$ & $3.9 \pm 0.2$ \\
\hline 1 & $4.3 \pm 0.1$ & $4.3 \pm 0.3$ & $4.1 \pm 0.2$ \\
\hline 2 & $4.3 \pm 0.2$ & $4.3 \pm 0.2$ & $4.2 \pm 0.1$ \\
\hline 3 & $4.3 \pm 0.2$ & $4.4 \pm 0.2$ & $4.3 \pm 0.2$ \\
\hline 4 & $4.3 \pm 0.2$ & $4.4 \pm 0.2$ & $4.3 \pm 0.3$ \\
\hline 5 & $4.4 \pm 0.3$ & $4.4 \pm 0.3$ & $4.4 \pm 0.2$ \\
\hline
\end{tabular}

Table 2. Total Yeast Counts (Log (cfu) $\mathrm{ml}^{1}{ }^{ \pm} \pm$S.D) During Mixed Culture Fermentation. Values are Means \pm S.D of Three Sets of Experiments with Triplicate in Each Set

\begin{tabular}{|c|c|c|c|}
\hline Day & Watermelon & Watermelon+Banana & Watermelon+Pineapple \\
\hline \hline 0 & $4.4 \pm 0.3$ & $3.7 \pm 0.1$ & $2.8 \pm 0.2$ \\
\hline 1 & $4.4 \pm 0.2$ & $3.7 \pm 0.2$ & $3.5 \pm 0.2$ \\
\hline 2 & $4.5 \pm 0.1$ & $3.6 \pm 0.1$ & $3.5 \pm 0.3$ \\
\hline 4 & $4.5 \pm 0.1$ & $3.6 \pm 0.1$ & $4.0 \pm 0.1$ \\
\hline 5 & $4.5 \pm 0.2$ & $3.7 \pm 0.2$ & $4.1 \pm 0.2$ \\
\hline
\end{tabular}


The watermelon-banana mixture medium had bacterial counts of $2.8-4.1 \pm 0.3 \log (\mathrm{cfu}) \mathrm{ml}^{1}{ }^{1}$ and yeast counts of $4.4-4.7 \pm 0.1 \log (\mathrm{cfu}) \mathrm{ml}^{1}{ }^{1}$ during the course of fermentation. The watermelon-pineapple mixture medium had the lowest bacterial and yeast counts of $2.7 \pm 0.1-4.1 \pm 0.3$ $\log (\mathrm{cfu}) \mathrm{ml}^{1}{ }^{1}$ and $4.4-4.6 \pm 0.1 \log$ (cfu) $\mathrm{ml}^{-}{ }^{1}$, respectively (Tables 3 and $\mathbf{4}$ ).

The mean sensory analysis of the fermented alcoholic beverages showed significant difference $(\mathrm{P}<0.05)$ in colour, taste, aroma and overall acceptability. The alcoholic beverages produced from the combination of watermelonpineapple mixture were the most favoured, having between 8.3 - 8.9 ranking. The watermelon-banana mixture followed with ranking of $6.4-7.7$ while the beverages from watermelon alone were of unacceptable characters in all the parameters evaluated, with a comparatively low ranking of 5.0 - 6.1 (Table 5).

\section{DISCUSSION}

Specific microbial species were isolated during the production of alcoholic beverages from some of the tropical fruits. Molds could not be isolated due to low level of oxygen as the Fermenters were air tight. It could as well be due to the enhanced level of acid produced by lactobacillus species. The fruits juice provided all the nutrients and favorable conditions necessary for microbial fermentation and, hence

Table 3. Total Bacterial Counts $\left(\log (\mathrm{cfu}) \mathrm{ml}^{-1}+\right.$ S.D) During Monoculture Fermentation. Values are Means \pm S.D of Three Sets of Experiments with Triplicate in Each $\bar{S}$ et

\begin{tabular}{|c|c|c|c|}
\hline Day & Watermelon & Watermelon+Banana & Watermelon+Pineapple \\
\hline \hline 0 & $3.0 \pm 0.1$ & $2.8 \pm 0.1$ & $2.7 \pm 0.1$ \\
\hline 1 & $3.7 \pm 0.2$ & $3.0 \pm 0.1$ & $2.8 \pm 0.1$ \\
\hline 2 & $3.7 \pm 0.3$ & $3.7 \pm 0.2$ & $3.4 \pm 0.1$ \\
\hline 3 & $3.9 \pm 0.1$ & $3.9 \pm 0.1$ & $3.8 \pm 0.4$ \\
\hline 4 & $4.0 \pm 0.1$ & $4.1 \pm 0.2$ & $4.0 \pm 0.1$ \\
\hline 5 & $4.1 \pm 0.3$ & $4.1 \pm 0.3$ & $4.1 \pm 0.2$ \\
\hline
\end{tabular}

Table 4. Total Yeast Counts $\left(\log (\mathrm{cfu}) \mathrm{ml}^{1}{ }^{1} \pm\right.$ S.D) During Monoculture Fermentation. Values are Means \pm S.D of Three Sets of Experiments with Triplicate in Each Set

\begin{tabular}{|c|c|c|c|}
\hline Day & Watermelon & Watermelon+Banana & Watermelon+Pineapple \\
\hline \hline 0 & $4.4 \pm 0.1$ & $4.4 \pm 0.1$ & $4.4 \pm 0.1$ \\
\hline 1 & $4.3 \pm 0.3$ & $4.6 \pm 0.1$ & $4.5 \pm 0.2$ \\
\hline 2 & $4.4 \pm 0.1$ & $4.6 \pm 0.1$ & $4.5 \pm 0.1$ \\
\hline 3 & $4.4 \pm 0.1$ & $4.6 \pm 0.1$ & $4.5 \pm 0.1$ \\
\hline 4 & $4.7 \pm 0.1$ & $4.6 \pm 0.2$ & $4.6 \pm 0.1$ \\
\hline 5 & $4.7 \pm 0.2$ & $4.7 \pm 0.1$ & $4.6 \pm 0.1$ \\
\hline
\end{tabular}

Table 5. Sensory Characteristics of the Alcoholic Beverage Produced from Tropical Fruits

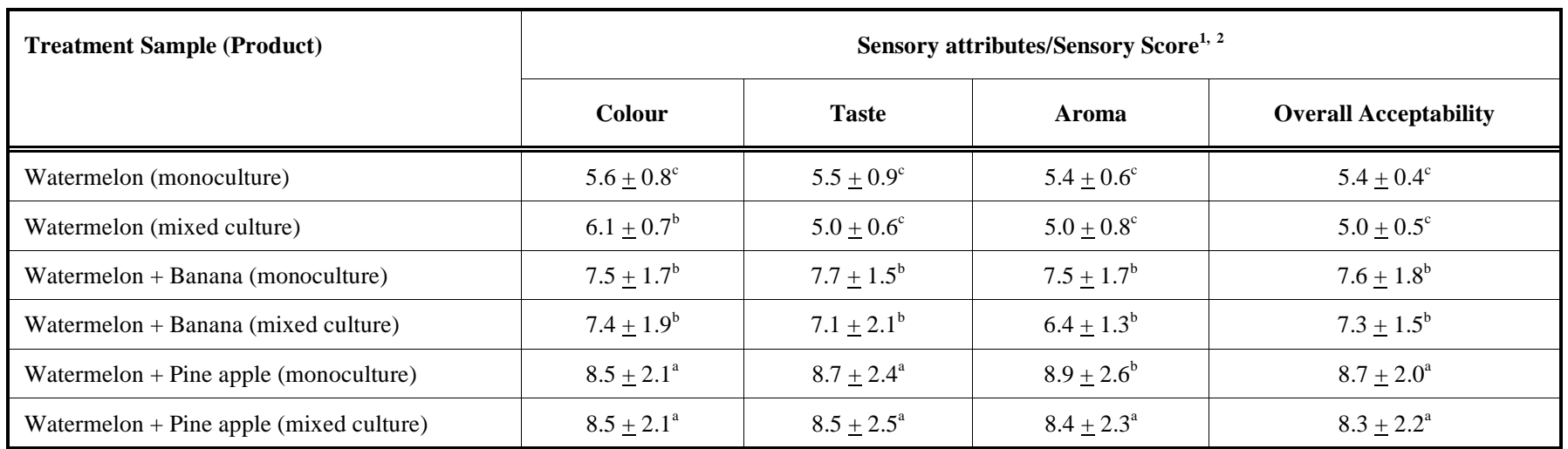

${ }^{1}$ Each of data is mean \pm SD 10 panelists where $1=$ dislike extremely, $2=$ dislike very much, $5=$ no preference, $6=$ like slightly, $7=$ like moderately, $8=$ like very much and $9=$ like extremely.

${ }^{2}$ Different letters within the score row are significantly different at $(\mathrm{P}<0.5)$. 
the fermenting musts were not induced with any artificial nutrient. The present study is in accordance with Ogbona [18] who demonstrated the fermentation of banana to palmwine with indigenous microflora and a desired wine product. Microorganisms are able to utilize certain carbohydrates such as fructose, galactose, lactose, maltose and mannitol as a source of energy $[19,20]$. It is, therefore, expected that some components of the fruits, especially sugars might have affected the relative growth rate of the different species of the isolated bacteria and yeasts. It has been well documented that yeasts utilize of sugars as their principal source of energy and this could account for the ease with which the various sugars present in the tropical fruits were utilized. This could be the reason for the lower bacterial and yeasts counts encountered in watermelon + banana and watermelon + pineapple beverages as compared to the beverage produced from watermelon as the former had lower sugar content. In spite of the variation in microbial counts in the various fermented substrates, a high microbial count was generally noted. This observation of the total colony counts may be due to the high water activities $\left(a_{w}\right)$ that led to an enhancement in the microbial successions in various fermented substrates.

Most of the stages involved in the alcoholic beverage production contributed to the successful attainment $[19,20]$ of a quality and desired quantity of alcoholic beverage from the tropical fruits. The crushing of the raw materials for the juice extractions increased the microbial accessibility in both the monoculture and mixed culture fermentations. It was noticeable that (a) due to the high microbial counts during fermentation, the alcoholic beverages could be liable to spoilage in a short span, if adequate storage facilities were not provided; (b) due to the low alcoholic contents of the beverages, physico-chemical preservation devices could be required to ensure safety during storage phenomenon.

\section{CONCLUDING REMARKS}

The different alcoholic beverages produced in the present study showed characteristic distinction among the treatments. It cannot be over ruled that the species of organisms involved in the spontaneous fermentation are influenced by the source of raw materials used for the beverage production and the ingredients of the fermenting mixtures. It appears that utilization of these fruits for beverage production by an individual would not lack the quality control, ultimately, failing to meet microbiological safety and other quality standards if only care could be managed over human contaminations. Conclusively, the qualities of the beverages as noticed might be manifestation of the components of the natural colour, taste and flavour of the fruits taken into consideration at laboratory level as well as large scale in industry.

\section{ACKNOWLEDGEMENTS}

An institutional research promotion grant to the Department of Biotechnology, College of Engineering and Tech- nology, Moradabad, U.P., India is acknowledged. The authors are grateful to Prof. R.M. Dubey (Managing Director) and Prof. A. Srivastav (Director), CET, IFTM, Moradabad, U.P, India) for providing the necessary facilities and encouragement.

\section{REFERENCES}

[1] Basilio ACM, De Aroujo PRL, De Morais JOF, Da Silva Filho EA, De Morais MA Jr, Simões DA. Detection and identification of wild yeast contaminants of the industrial fuel ethanol fermentation process. Curr Microbiol 2008; 56: 322-26.

[2] Cole VC, Noble AC. Flavour chemistry and assessment. In: Led AGH, Piggot IR Eds. Blackie Academic and Professional, Glasgow 1995; pp. 361-385.

[3] Allan W. Industrial Microbiology. Hong Kong, Macmillan Publishers 1983; pp. 112-23.

[4] Benda I. Industrial Microbiology. $4^{\text {th }}$ ed. West Part: AVI Publishing Co, Conn. 1982; pp. 293-402.

[5] Smihitte A, Curshman K, Mittenbergee A, Koehler A. Active dry wine yeast compared over several years (Germen). Der Deitscje Weinban 1984; 25/26: pp. 1126-38.

[6] Rodríguez-Porrata B, Novo M, Guillamon J, Rozes N, Mas A, Cordero Otero R. Vitality enhancement of the rehydrated active dry wine yeast. Int J Food Microbiol 2008; 126: 116-22.

[7] Shuts M, Gather J. Analysis of yeast diversity during spontaneous and induced alcoholic fermentations. J Appl Bacteriol 1993; 75: 551-8.

[8] Queril A, Barrio E, Ramon D. Population dynamics of natural Saccharomyces strains during wine fermentation. Int J Food $\mathrm{Mi}$ crobiol 1994; 21: 253-9.

[9] Jemec KP, Cadez N, Zagorc T, Bubic V, Zupec A, Raspor P. Yeast population dynamics in five spontaneous fermentations of Malvasia must. Food Microbiol 2001; 18: 247-59.

[10] Santamaria P, Garizo P, Lopez R, Tenorio C, Gutierrez AR. Analysis of yeast population during spontaneous alcoholic fermentation: Effect of the age of the cellar and the practice of inoculation. Int $\mathbf{J}$ Food Microbiol 2005; 103: 49-56.

[11] Madigan MT, Martinko JM, Parker J. Direct measurement of microbial growth. In: Brock Biology of Microorganisms, $8^{\text {th }}$ ed. Upper Saddle River, New Jersey: USA, Prentice-Hall Inc 1997; p. 156.

[12] Holt JG, Kreig NR, Sneath PH, et al. Bergey's Manual of Determinative Bacteriology. Baltimore: William and Willikins Publishers 1994.

[13] Kreger VR. The yeast. In: A Taxonomic Study, $3^{\text {rd }}$ ed. Amsterdam Elsevier 1984; pp. 55-7.

[14] Ghadge PN, Prasad K, Kadam PS. Effect of fortification on the physic chemical and sensory properties of buffalo milk yoghurt. EJEAFChe 2008; 7: 2890-9.

[15] Akoma O, Onuoha SA, Ajiboye MO, Akoma AO, Alawoki AM. The nutritional and sensory quality characteristics of kunun-zaki produced with the addition of hydrolytic enzymes from malted rice (Oryza sativa). J Food Technol Afr 2002; 7: 24-6.

[16] Akoma O, Jiya EA, Akumka DD, Mshelia E. Influence of malting on the nutritional characteristics of kanun-zaki. Afr J Biotechnol 2006; 5: 996-1000.

[17] Duncan DB. Multiple range and F-test. Biometrics 1955; 1: 1-10.

[18] Okafor N. Microbiology of Nigerian Palm wine with particular reference of bacteria. J Appl Bacteriol 1993; 38: 81-8.

[19] Uzchukwu S, Balogh E, Tucknot OG, Lewis MJ, Ngoddy PO. Role of palm wine yeasts and bacteria in palm wine aroma. J Food Sci Technol 1999; 36: 301-4.

[20] Amoa-Awua WK, Sampson E, Tano-Debrah K. Growth of yeasts, lactic and acetic acid bacteria in palm wine during tapping and fermentation from felled oil palm (Elaeis guineensis) in Ghana. J Appl Microbiol 2007; 102: 599-606. 